\title{
Genetic mechanisms of the resistance of Escherichia coli to amino acid antimetabolites. 2. Study of the frequency of induction and properties of glyphosate resistant mutants
}

\author{
E. Cherepenko
}

Institute of Molecular Biology and Genetics, National Academy of Sciences of Ukraine 150 Zabolotnogo str., Kiev, 252143

\begin{abstract}
The friquency of the induction by nitrosoguanidine of glyphosate resistant nutants was compared for recipient and donor, as well as for lysogenic and non-lysogenic E. coli cells. It was found that integration of viral genomes and also larger replicons such as F-factor into host chromosome increased the level of glyphosate resistance by the factor ranging from 1.6 to 6 . Mutants tolerating $0.2 \mathrm{mM}$ of the inhibitor were. obtained one order of magnitude more frequently than mutants tolerating $1 \mathrm{mM}$ of this inhibitor. One half of the mutants of every group were resistant not only to the analogue of glycine,but also to the analogue of lysine. An attempt to clone an insertion from a gene library of one of the mutants was attempted but failed. Study on the nature of this gene is in progress.
\end{abstract}

Introduction. Antimetabolites are extensively used as drugs and pesticides and are widely studied as «lead» compounds in «drug design» programs [1] (for rev. see $[2,3])$. However in practice cellular drug resistance developing in different taxonomic groups makes the use of such inhibitors less efficient. What is genetic and molecular basis of such a resistance? To investigate this the well-studied mechanisms of glyphosate inhibition may be used as a good experimental model.

The broad-spectrum non-selective herbicide glyphosate $\mathrm{N}$-Iphosphonomethyl I-glycine specifically inhibits the 5-enolpyruvylshikimate-3-phosphate synthase (EPSPS), which catalyses the sixth step in the shikimate biosynthetic pathway the occurence of which is restricted to bacteria, fungi and plants [4]. Mutational changes rendering this enzyme insensitive to the inhibitor, as well as target site overproduction due to gene amplification (or specific promoter changes) have been shown to lead to the glyphosate resistance (for rev. see [5]). However these events as well as reduced inhibitor uptake, increase in its

(C) E. ChEREPENKO, 1997 degradation are rare events $[6-8]$, whereas the probability of glyphosate-resistant $\left(\mathrm{gly}^{\mathrm{r}}\right)$ colonies appearance is 2 orders of magnitude higher in $E$. coli [6]. We have recently shown that most of the glyr clones are single gene mutants which are mapped at 4 different loci of the $E$. coli chromosome map [9]. We wondered if integration of different replicons into the host chromosome have an effect on the probability of the appropriate gene mutability. To answer this question the induction probability of gly $^{r}$ mutants in recipient and donor as well as lysogenic and nonlysogenic $E$. coli cells was measured.Also the nature of the mutants obtained was studied.

Materials and Methods. Chemicals. N-methyl-Nnitro-nitrosoguanidine (NG) and S-2-amino-ethyl-Lcysteine were supplied by «Sigma» (Germany). As a source of glyphosate the commercial herbicide Roundup $^{(R)}$ with the isopropylamine salt of glyphosate as an active ingredient was used.

Bacterial Strains and Growth Media. The E. coli strains employed and their genotypes are listed in Table 1. As basal salt media, M9 and LB medium were used [10].

Mutagenesis and Genetic Methods. For mutagenesis, nitrosoguanidine treaiment was employed as 
Table 1

Strains used

\begin{tabular}{|c|c|c|c|c|c|}
\hline$N$ & Sex & Strain & Relevsut genotype & Prophage & Source. \\
\hline 1 & $\mathbf{F}^{-}$ & $A B: 157$ & $\begin{array}{l}\text { thr- } 1, \text { thi- } 1, \text { lacy-1, mtl-1, xylls, galK2, pro } 42, \\
\text { argE } 3, \text { str } 31, \text { ts } 33, \text { sup } 37, \text { leu6, ara, his } 4 C\end{array}$ & None & $\begin{array}{l}\text { Dr. V. I antzov, Inst. of Nucl. } \\
\text { Res. (Russia) }\end{array}$ \\
\hline 2 & $\mathrm{li}^{-}$ & $A B_{1}: 57$ & The same & $\lambda^{\operatorname{lmm} 434}$ & Lysogenized in this work \\
\hline 3 & JIfr & C & Prototrophic & $\dot{\lambda}$ & $\begin{array}{l}\text { Dr. V. Lautzov, Inst. of Nucl. } \\
\text { Res. (Russia) }\end{array}$ \\
\hline 4 & HIfr & B2625 & The same & None & $\begin{array}{l}\text { Inst. Industr. Microbe Genet. } \\
\text { and Selection (Russia) }\end{array}$ \\
\hline 5 & Her $P_{3}$ & B346 & cys, gal $a,{ }^{-} T_{1}{ }^{r}, T_{3}{ }^{r}$ & None & Ibid \\
\hline 6 & $F^{-}$ & DHF $5 \alpha$ & $\begin{array}{c}\text { supE44, DlacUI69(p8olacZDM15), hsdR17, } \\
\text { recAl, cndA1, gyrA96, thil, relA }\end{array}$ & None & Ibid \\
\hline 7 & $F^{-}$ & HB- 101 & $\begin{array}{c}\text { supE44, hsd } S 20\left(\mathrm{r}_{B}^{-} \mathrm{mB}^{-}\right) \mathrm{rec} A 13, \text { aral4, proA2, } \\
\text { lacY1, galK2, rps } 20, \text { xyll5, mtll }\end{array}$ & None & Ibid \\
\hline
\end{tabular}

Table 2

Average number* of gly mutants per $10^{\circ}$ of mutagenized $E$. coli cells appearing after NG treatment

\begin{tabular}{|c|c|c|c|c|c|}
\hline Strain & Relevant zenotype & \multicolumn{4}{|c|}{ Nuzaber of survivors at increasing doses of glyphosale" } \\
\hline $\mathrm{AB}_{1157}$ & Recipient nonlysogenic & 0 & 300 & 150 & 25 \\
\hline $\mathrm{AB}_{1157}$ & Recipient lysogenic & 0 & 400 & 300 & 40 \\
\hline Hfr C & Donor lysogenic & 0 & 1000 & 500 & 150 \\
\hline $\mathrm{Hfr} \mathrm{P}_{3}$ & Donor & 0 & 400 & 200 & 40 \\
\hline
\end{tabular}

*Not less than 3 experiments; **because Roundup ( $300 \mathrm{~g} / 1$ of isopropylammonium salt of glyphosate) was used, 1 dose was determined as the minimal quantity required to suppress growth of all untreated cells in control.

described by Miller $[10]$. Gly mutants obtained in primary selection experiments were studied by a passage on increasing concentration of glyphosate alone or a mixture of glyphosate and AEC $(200 \mu \mathrm{g} / \mathrm{ml})$.

Construction of gly mutant genomic DNA library and complementation. DNA isolated from this mutant was partially digested with $S a u 3 A$ and fractionated on a $0.8 \%$ agarose gel. Fragments smaller than $3 \mathbf{~ k b}(\lambda$ DNA HindllI markers) were recovered from the gel using the glassmilk procedure (Bio101, Inc). Analogously molecules of BamHl digested, dephosphorylated Bluescript $\mathrm{SK}^{+}$vector (from «Stratagene», USA) were recovered from the gel. The fragments from the two sources were ligated in a ratio of $1: 1$ (total $40 \mathrm{ng}$ of DNA used) at $4{ }^{\circ} \mathrm{C}$ overnight [11] and were used to transform cells of competent $E$. coli strain DH5a (from Bethesda Res. Lab). Diluted aliquots of the transformed cells were plated on L.B agar containing ampicillin at $50 \mu \mathrm{g} / \mathrm{ml}$ and $\mathrm{X}$-gal and IPTG thus allowing to determine the percent of plasmids having DNA inserts [11].

The remainder of the transformants were inoculated into $3 \mathrm{ml}$ of $\mathrm{LB}$ supplemented with ampicillin and incubated overnight at $37^{\circ} \mathrm{C}$. A plasmid library was generated by harvesting the plasmids by alkaline lysis [11]. The library obtained was used to transform both $\mathrm{DH} 5 \alpha$ and $\mathrm{HB}-101$ cells made competent following the method of Hanahan [12 ]. The transformants were plated on M9 medium containing different concentrations of glyphosate and all auxothrophic additions required.

Results and Discussion. The frequency of the induction of gly mutants by NG for different $E$. coli cells represented by recipient - donor and lysogenicnonlysogenic cells are shown in Table 2 . 
Table 3

Number of mutants tolerating increasing doses of glyphosate and AEC

\begin{tabular}{|c|c|c|c|c|}
\hline \multirow{2}{*}{ Sirain } & \multicolumn{2}{|c|}{ Giyphosate dosc } & \multicolumn{2}{|c|}{ Glyphosate dose + AEC (200 $\left.\mu_{B} / \mathrm{mI}\right)$} \\
\hline & I dose & 2.5 dose & 1 dose & 2.5 dose \\
\hline Hfr $C \lambda^{r}$ & 50 & Not studied & 25 & Not studied \\
\hline $\mathrm{Hfr} C \lambda^{s}$ & 50 & Not studied & 35 & Not studied \\
\hline Iffr $P_{3}$ & 47 & 12 & 18 & 7 \\
\hline
\end{tabular}

From the results shown in Table 2 it can be concluded that integration of different replicons into the host chromosome slightly increased the probability of a gly mutation. The increase was more pronounced in the strain with both $F$-factor and $\lambda$ replicons integrated not far from each other (about 10 min on the $E$. coll chromosome map). As was shown earlier, the mutations obtained in this strain map at 4 different loci [9].

On the basis of their tolerance to increasing doses of the inhibitor, mutations obtained could be divided

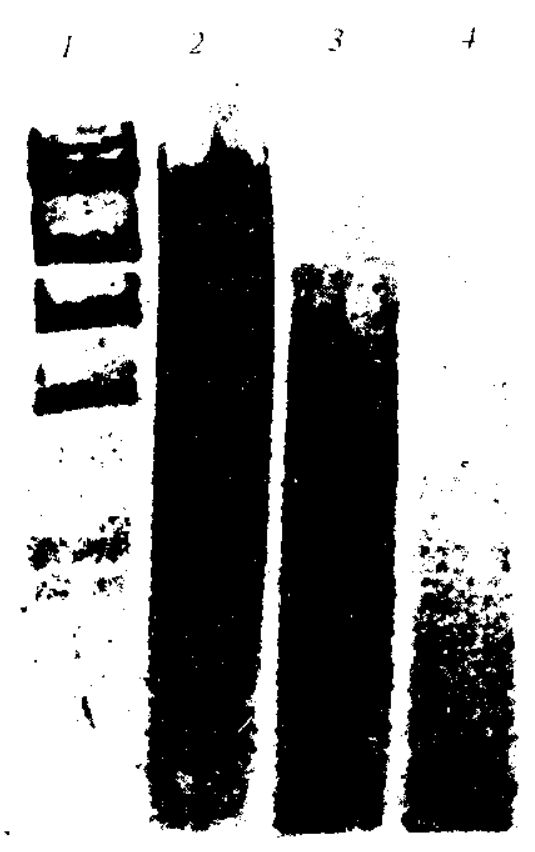

Fig. 1. Partia digestion of gly' mutari genomic DNA with Sau3A restriclion endonuclease lanes: $1-\lambda D N A$ Hind $I I I$ markers; $2-4-$ dynamics of a mutant DNA $(7 \mu \mathrm{g})$ hydrolysis for 20,40 and 60 min appropriately with 4 units of the enzyme into 2 groups, $i$. e. those tolerating low doses and those tolerating higher doses. The frequency of the first group is one order of magnitude higher than the other. The frequency of mutants resistant to both glyphosate and $\mathrm{AEC}$ is evident from Table 3.

The results in Table 3 demonstrate that almost half of the mutants tolerating both low and higher doses of glyphosate also tolerated a toxic analogue lysine and thus were multiple-resistant.

Thus, gly mutants appearing after NG treatment constitute $\mathbf{4}$ different groups tolerating different doses

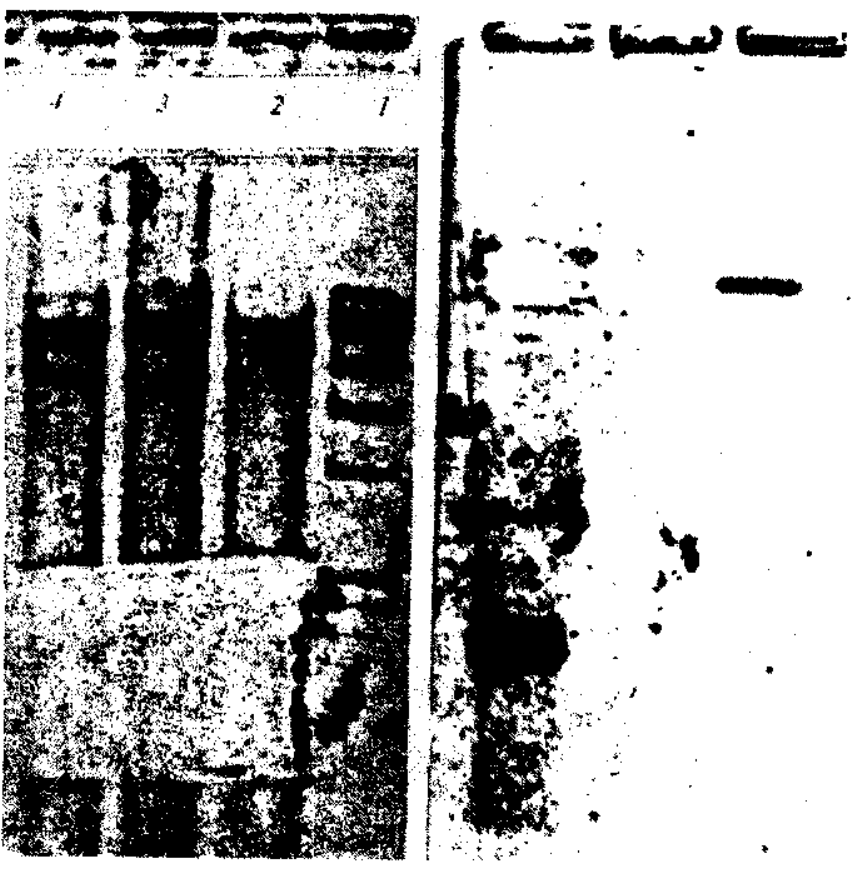

Fig. 2. Demonstration of the size of DNA fragments used for gene library construction lanes: $l-\lambda$ DNA Hind $I I I$ markers; $2-4-g l y^{\mathrm{r}}$ mutant genomic DNA $(10 \mu \mathrm{g})$ hydrolysed with Sau3A

Fig. 3. Purification of Bluescript $\mathrm{SK}^{+}$vector DNA using glassmilk procedure (Biol01, Inc.) 
of glyphosate and cross-resistant to AEC. How many genes are involved in this phenotype and what is their nature?

Because $m d r$ genes in eukaryotes are responsible for multidrugresistance based on drug efflux out of the cell (for rev. see [13]), and as such a gene should be dominant over its wild type allele the cloning of multiresistant gly ${ }^{r}$ mutant DNA was tried. This mutant DNA was partially digested with $\operatorname{Sau} 3 A$ (Fig. 1 ), fragments of $\approx 2 \mathrm{~kb}$ recovered from the gel (Fig. 2) and ligated to the vector (Fig. 3) (see Materials and Methods). Thus, approximately $80 \%$ of the transformants produced due to the ligation product were of white color on the indicator plates and the number of inserts obtained was about 10000 . Using this library, DH5a and HB-101 cells were transformed and after washing with M9 medium plated on selective medium containing 1 dose of glyphosate. A couple of white colonies were obtained in both cases but none of them were highly efficient in retransformation experiments and consequently the gene was not cloned. It this gene codes for a recessive trait another approach should be used [9] and this work is now in progress.

Acknowledgements. I appreciate the helpful discussions with professor Nikolaus Amrhein (ETH, Zurich). I thank professor Sydney Craig (UNC, Chapel Hill) for letting me use his lab to construct the gene library. The excellent technical assistance of Oxana Karpenko is also gratefully acknowledged.

\section{О. Й. צерепенко}

Генетичні механізми стійкості клітин Escherichia coli до амінокислотних антиметаболітів. 2. Вивчення частоти індукціі 'га властивостей гліфосатстійких мутантін

Резюме

Вивнено частоту індукцї гліфосатстійких мутантів у рещипіент-донорських, а також лізосенних-нелізогенних итамах ктітин E. coli. Показано, що інтеграція вірусного, а також більцого F-реплікона підвищуе частоту індукцї гліфосатстійких мутантів від 1,6 до б разів. Мутанти, стійки до 0,2 мМ сліфосату, виникають у I0 разів частіше мутантів, стійких до I мМ иього аналога гліцину. Половина мутантів кожної групи стійка не лиие до аналога гліцину, але й до аналога лізину. Клонувати ген гліфосатстійкості ке вдалося. Досліджустося домінантно-рецесивна природа цього гена.

\section{E. И. Черепенко}

Генетические механизмы устойчивости клеток Escherichia coli $\mathrm{k}$ аминокислотным антиметаболитам. 2. Изучение частоты индукции и свойства глифосатустойчиных мутантов

Резюме

Изучена частота индукции слифосатустойчивых мутантов в реципиект-донорских, а также лизогенных-нелизосенных итаммах. Показано, ито интеграция вирусного и более крупного F-репликона увеличивает часпоту индукции gly ${ }^{r}$-мутанmos om 1,6 to 6 раз. Мутанты, устойчияые $\kappa \quad 0,2$ мM глифосата, возникают в 10 раз тице таковых, устойчивых $\kappa$ I мМ этого аналога глицина. Половина мутантов каждой группы устойчгвва не молько к аналогу глищина, но и к апалогу лизина Клонировать ген глифосатустойчивости не удалось. Изучается доминантно-рецессивная природа этого гена.

\section{REFERENCES}

1. Eakin A., Nieves-Alicea $R$., Tosado-Acevedo $R$. et al. Comparative compliment selection in bacteria enables screening for lead compounds targeted to a purine salvage enzyme of parasites // Antimicrob. Agents and Chemother.-1995.39.-P. 620-625

2. Craig S. Purine salvage enzymes as targets for the chemotheurapeutic treatment of parasitic diseases // Biopolymers and Cell. - 1994.-10, N 6.-P. 65--71.

3. Bugg Ch, Carson W., Montgomery J. Drugs by design // Sci. Amer.-1993.-269.-P. 92-98.

4. Steinrucken H., Amrhein N. The herbicide glyphosate is a potent inhibitor of 5-enolpyruvyl-shikimic acid-3-phosphate synthase // Biochem. and Biophys. Res. Communs. - 1980.94.-P. $1207-1212$.

5. Kishore $G$. Shah $D$. Aminoacid biosunthesis inhibitors as herbicides // Ann. Rev. Biochem.-1988.-57-P. 627-663.

6. Comai $L$, Sen $L$, Stalker $D$. An altered aroA gene product confers resistance to the herbicide glyphosate // Science.1983.-221.-. P. 370-371.

7. Amrhein N., Johaning D., Schab J. et al. Biochemical basis for glyphosate-tolerance in a bacterium and a plant tissue culture // FEBS. $-1983 .-157 .-$ P. $191-196$.

8. Cherepenko $E$. Gene amplfication and herbicide-tolerance // Biopolymers and Cell. -1993.-9, N 3.-P. 3-16.

9. Cherepenko E., Karpenko O., Maliata S. Genetic mechanisms of Escherichia coli resistance to amino acid antimetabolites // Ibid. - 1994.-10, N 4.-P. 79-82.

10. Miller J. Experiments in Molecular Genetics. -New York: Cold Spring Harbor Lab., 1972.

11. Sambrook J., Fritsch E., Maniatis T: Molecular cloning. A Laboratory Manual.--New York: Cold Spring Harbor Lab., 1989.

12. Hanahan D. Studies in transformation of Escherichia coli with plasmids // J. Mol. Biol._-1983.-166.-P. 557-580.

13. Endicott J., Ling $V$. The biochemistry of P-glycoproteinmediated multidrug resistance // Annu. Rev. Biochem.-1989. -58. - P. 137-149.

Received 24.02.97 